\title{
Effects of Cultural Temperatures on Antioxidant Levels in Leaves of Cattleya and Cymbidium
}

\author{
Jincai Li, Shichiro Matsui* and Siaw Onwona-Agyeman* \\ The United Graduate School of Agricultural Science, and *Faculty of Agriculture, Gifu University, \\ Gifu 501-1193, Japan
}

(Received April 5, 2000)

\begin{abstract}
Orchids of Brassolaeliocattleya Chian-Tzy Emperor (Cattleya) and Cymbidium Sazanami were cultured at $32 / 20^{\circ} \mathrm{C}, 30 / 15^{\circ} \mathrm{C}$, and $28 / 8^{\circ} \mathrm{C}$ (maximum/minimum temperature) for 2 months. It was found in Cattleya leaves that superoxide dismutase (SOD), ascorbate peroxidase (APX) and catalase (CAT) activities were lower than in Cymbidium leaves, while polyphenol oxidase (PPO) and ascorbate oxidase (AOX) activities were higher. The high cultural temperature enhanced activities in all enzymes in Cattleya and in four enzymes except CAT in Cymbidium, indicating that it greatly affects scavenging enzyme activities compared to the low temperatures which induced only an increase in APX activity in Cattleya and a decrease in CAT activity in Cymbidium. PPO activity increased and AOX decreased in both orchids at the low temperature. Cattleya leaves at both high and low cultural temperatures decreased ascorbic acid, while Cymbidium increased it. Cattleya at the low temperature increased markedly SH-containig substances but the latter at the high temperature decreased these substances. Lipid peroxides increased in Cymbidium leaves under both high and low temperatures, but for Cattleya neither temperature conditions affected lipid peroxides.
\end{abstract}

Keywords : antioxidant level, Cattleya, cultural temperature, Cymbidium

\section{INTRODUCTION}

Commercial orchids such as cattleyas and cymbidiums are cultivated in greenhouses in the winter season and outdoors in summer. In order to force Cymbidium culture, plants are transferred to mountain ranges in summer in order to ensure flower bud development and then brought back to greenhouses in autumn. To delay flowering, they are grown in non-heated greenhouses during winter and bloom in early spring. However, sudden frost damages distress growers. Unendurable heat stress induces physiological disorders like the burning, dropping of flower buds (Northen, 1970) and leaf bleaching (Powles, 1984). Thus, orchid production is accompanied by several cultural methods requiring adequate care for cultural temperatures and light intensity. Available reports indicate that very little work has been done on acclimation of orchids.

As oxygen levels are high in plant tissues due to photosynthesis, abiotic stresses such as temperature, light and gases as well as biotic stresses yield much reactive oxygen species (ROS) in leaf tissues. To detoxify such ROS, plants enhance activities in oxygen-scavenging enzymes

Corresponding author : Shichiro Matsui, Fax: +81-58-293-2977, e-mail: mash @ cc.gifu-u.ac.jp 
and antioxidant levels in their leaves. Superoxide dismutases (SOD) play a primary role in defensive reactions of aerobic organisms to ROS (Fridovich, 1986) and detoxify superoxide $\left(\mathrm{O}_{2}{ }^{-}\right)$with NADPH at PSI to yield $\mathrm{H}_{2} \mathrm{O}_{2}$ (Scandalios, 1993). Asorbate peroxidases (APX) located in chloroplasts and cytosols are known to decompose $\mathrm{H}_{2} \mathrm{O}_{2}$ (Asada, 1992 ; Alscher et al., 1997). It has also been reported that catalase (CAT) decomposes $\mathrm{H}_{2} \mathrm{O}_{2}$ in peroxisomes (Salin, 1988; Asada, 1992). Increases in SOD activity by induction of stresses were shown in a chilling tolerant Zea diploperennis (Jahnke et al., 1991) and in chilling-tolerant and sensitive cucumbers (Shen et al., 1999). Increased APX activities in corn plants grown in an elevated $\mathrm{O}_{2}$ level (Foster and Hess, 1982), in a $\mathrm{C}_{4}$ plant of a habitat in a cold climate (Hakam and Simon, 1996) and in a Zea plant (Jahnke et al., 1991) were also reported. Moreover, levels of antioxidants are correlated with growth irradiance and photosynthetic capacity (Grace and Logan, 1996).

Cattleyas and miniature cymbidiums are abundantly produced for cut flowers and potted plants. Parental species of the former are crassulacean acid metabolism (CAM) plants (Avadhani et al., 1982) that originate in areas of the tropic American Continent surrounded by an isothermal line of $27^{\circ} \mathrm{C}$ and relatively tolerant to hot weather. The latter hybrids are obtained by crossing oriental species which originate from areas showing an isothermal line of $21^{\circ} \mathrm{C}$ in East Asia and relatively tolerant to cold but not to heat (Karasawa, 1972). They are $\mathrm{C}_{3}$ plants.

In this paper, an attempt was made to clarify the effect of cultural temperatures, one of the determinant factors for their habitations, on defensive reactions to ROS caused by thermal stress. Findings obtained may serve as acclimation methods and an indicator(s) to predict presumable disorders induced by cold and heat stresses.

\section{MATERIALS AND METHODS}

Plant materials. Twelve potted plants of Brassolaeliocattleya Chian-Tzy Emperor 'CTGolden Sun' (referred to as Cattleya) and Cymbidium Sazanami 'Haru-no-umi' were grown in a $30 \%$ shaded greenhouse through summer and autumn. On 10th November, they were transferred to three rooms which were shaded at $60 \%$ of full sunlight intensity and in which temperatures were controlled at $32 / 20^{\circ} \mathrm{C}, 30 / 15^{\circ} \mathrm{C}$ and $28 / 8^{\circ} \mathrm{C}$ (maximum/minimum temperature). The plants were exposed to natural sunshine condition, irrigated every $3 \mathrm{~d}$ and dressed with aqueous Hyponex fertilizer every $20 \mathrm{~d}$. Leaves of both orchids were collected for determination of ROS-scavenging enzymes and antioxidant concentrations from nine o'clock to nine thirty 60 and $75 \mathrm{~d}$ after the treatment, respectively. Collected leaves weighing $2 \mathrm{~g}$ were sliced into small pieces, and stored below $-20^{\circ} \mathrm{C}$ after freezing with liquid nitrogen.

Enzyme extraction and assay.

SOD: Two grams of samples were ground in $8 \mathrm{ml}$ of $0.1 \mathrm{~mol}$ phosphate-borate buffer ( $\mathrm{pH}$ 7.8) with $1 \mathrm{mmol}$ EDTA, $3 \mathrm{mmol}$ DDT and $4 \%(\mathrm{w} / \mathrm{v})$ PVP. After the macerate was filtered through coarse cheesecloth the filterate was centrifuged at $10,000 \times g$ for $20 \mathrm{~min}$. The supernatant was used for crude enzyme extract. The activity was determined using the Nitro-Blue Tetrazolium (NTB) reduction method (Beauchamp and Fridovich, 1971). One unit of SOD activity was defined as the amount of enzyme required to cause $50 \%$ inhibition of the rate of NTB reduction measured at $560 \mathrm{~nm}$.

$A P X$ : Crude enzyme extract was prepared by grinding $2 \mathrm{~g}$ samples in $8 \mathrm{ml}$ of $50 \mathrm{mmol}$ phosphate buffer ( $\mathrm{pH} 7.0$ ). The reaction was initiated by adding $1 \mathrm{ml}$ of $5 \mathrm{mmol} \mathrm{H}_{2} \mathrm{O}_{2}$ to the reaction mixture composed of $0.4 \mathrm{ml}$ of the crude enzyme extract, $1 \mathrm{ml}$ of $0.2 \%$ ascorbic acid and $2 \mathrm{ml}$ of water. After $2 \mathrm{~min}, 1 \mathrm{ml}$ of metaphosphoric acid was added to terminate the reaction. Ascorbic acid consumption by ascorbate oxidase (AOX) activity was determined 
by adding the same volume of the enzyme extract to the reaction mixture composed of $1 \mathrm{ml}$ of $0.2 \%$ ascorbic acid and $3 \mathrm{ml}$ of water. The remaining ascorbic acid was titrated with $0.005 \mathrm{~N}$ iodine reagent.

CAT: Samples weighing $2 \mathrm{~g}$ were ground with $4 \mathrm{ml}$ of water and $0.4 \mathrm{~g}$ calcium carbonate. After centrifugation of the macerate, $1 \mathrm{ml}$ of the supernatant was diluted with $9 \mathrm{ml}$ of water. The diluted solution was used for a crude enzyme extract. Aliquot of enzyme extract $(3 \mathrm{ml})$ was mixed with $2 \mathrm{ml}$ of $3 \% \mathrm{H}_{2} \mathrm{O}_{2}$, after which the $\mathrm{O}_{2}$ evolved was estimated 6 min afterwards.

Polyphenol oxidase (PPO) and AOX: Crude enzyme extract was prepared by grinding $2 \mathrm{~g}$ samples in $50 \mathrm{ml}$ of $1 / 15 \mathrm{mmol}$ phosphate buffer $(\mathrm{pH} \mathrm{6.0)}$ ). The reaction for PPO activity was initiated by adding $2 \mathrm{ml}$ of the crude enzyme extract to the reaction mixture composed of $2 \mathrm{ml}$ of $0.2 \%$ ascorbic acid, $1 \mathrm{ml}$ of $30 \mathrm{mmol} o$-catechol and $4 \mathrm{ml}$ water. The catechol solution was replaced by water for determination of AOX activity. After $10 \mathrm{~min}, 1 \mathrm{ml}$ of metaphosphoric acid was added and the remaining ascorbic acid was estimated.

Antioxidant, peroxide and organic acid extraction and determination.

Ascorbic acid: Two grams of plant materials were macerated with 5\% metaphosphate. The assay was performed by the 2,4-dinitrophenyl hydrazine method (Roe et al., 1948).

SH containing substances (SHS): The $2 \mathrm{~g}$ samples were extracted with $8 \mathrm{ml}$ of $0.05 \mathrm{~m}$ Tris-HCl buffer ( $\mathrm{pH} 8.0$ ) including 3 mmol EDTA, 5 mmol DTT, $1 \mu$ mol leupeptin hemisufate and $0.83 \%$ casein and the assay was performed using Ellman's reagent (Ellman, 1959). Absorbance of $1.2 \mathrm{ml}$ of a sample extract mixed with $1.2 \mathrm{ml}$ of $0.2 \mathrm{~mol}$ phosphate buffer $(\mathrm{pH}$ 8.0 , containing $10 \mathrm{mmol}$ EDTA) was determined at $412 \mathrm{~nm}$. Then, the absorbance of a mixture of this sample and $0.1 \mathrm{ml}$ of $10 \mathrm{mmol}$ dithiobis (2-nitrobenzoic acid) was again determined at the same wavelength.

Lipid peroxides: Fifty grams of leaves were ground in hexane 3 times and then extracted with $150 \mathrm{ml}$ of $80 \%$ alcohol 3 times. Lipid peroxides were determined according to the TBA (2-thiobarbituric acid) method (Tien and Aust, 1982). Red TBA oxidized with lipid peroxides was measured at $535 \mathrm{~nm}$, and calculated in terms of malondialdehyde.

Organic acids: Acids in $20 \mathrm{ml}$ water extracts prepared from $5 \mathrm{~g}$ leaves were titrated with $0.1 \mathrm{~N} \mathrm{NaOH}$. Their concentrations were calculated in terms of citric acid.

\section{RESULTS}

\section{Oxygen-scavenging enzymes}

SOD, APX and CAT activities in leaves of Cattleya and Cymbidium plants cultured at the different temperature are shown in Fig. 1. They were markedly lower in the former plants
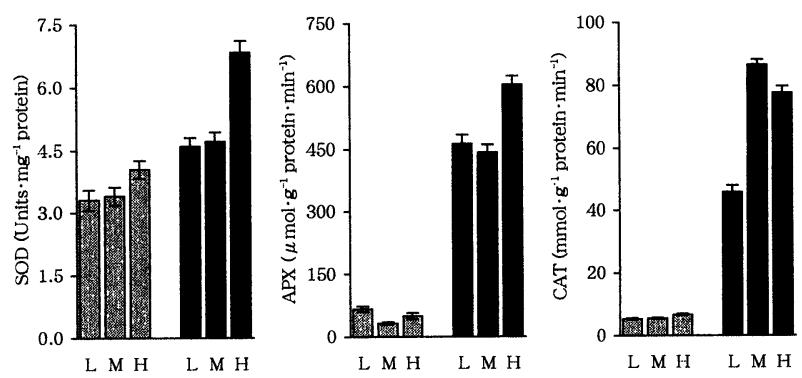

Fig. 1 Activities in superoxide dismutase (SOD), ascorbate peroxidase (APX) and catalase (CAT) in leaves of Cattleya ( and Cymbidium ( $)$ plants cultured at different temperatures. $\mathrm{H}: 32 / 20^{\circ} \mathrm{C}$ (maximum and minimum temperature), $\mathrm{M}: 30 / 15^{\circ} \mathrm{C}, \mathrm{L}: 28 / 8^{\circ} \mathrm{C}$. Vertical bars indicate SE $(n=4)$. 
than in the latter. Besides, they were varied within the plants grown at different cultural temperatures. In both plants SOD activity was significantly higher at the $32 / 20^{\circ} \mathrm{C}$ temperature condition than at $30 / 15^{\circ} \mathrm{C}$, but not different between at $28 / 8^{\circ} \mathrm{C}$ and $30 / 15^{\circ} \mathrm{C}$. High APX activities were found in Cattleya plants at the high and low temperatures and in Cymbidium at the high temperature. However, CAT activities did not differ among Cattleya plants cultured at the different temperatures but decreased in Cymbidium cultured at either high or low temperatures. Foliar PPO and AOX activities were markedly higher in Cattleya than in Cymbidium (Fig. 2). The former enzyme in both Cattleya and Cymbidium was more activated at both high and low cultural temperatures, while AOX activities were positively dependent on a rising cultural temperature.

\section{Antioxidant and peroxide levels and organic acids}

Ascorbic acid concentration in Cattleya leaves cultured at $30 / 15^{\circ} \mathrm{C}$ was markedly higher than in Cymbidium ones at the same temperature. Cattleya at $32 / 20^{\circ} \mathrm{C}$ and at $28 / 8^{\circ} \mathrm{C}$ decreased ascorbic acid concentration, while at the same conditions Cymbidium increased it markedly. SHS in Cattleya leaves was highest at $28 / 8^{\circ} \mathrm{C}$. Contrary to Cattleya, SHS was significantly lower in Cymbidium at $32 / 20^{\circ} \mathrm{C}$ than at $30 / 15^{\circ} \mathrm{C}$. Lipid peroxide concentrations in leaves did not significantly vary with Cattleya plants cultured at different temperatures, while those of Cymbidium cultured at both high and low temperatures increased significantly. Organic acid concentrations in Cattleya leaves at any cultural temperature were markedly higher than in Cymbidium. They were lower in both Cattleya and Cymbidium plants at
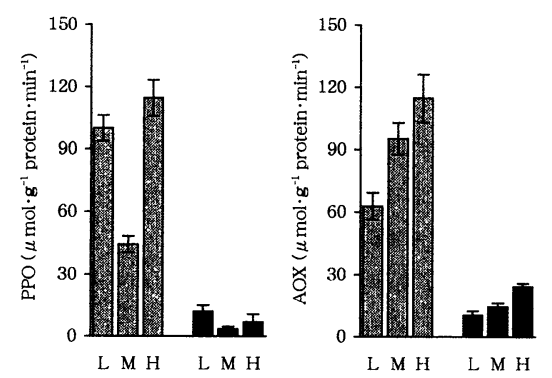

Fig. 2 Activities in polyphenol oxidase (PPO) and ascorbate oxidase (AOX) in leaves of Cattleya (10) and Cymbidium ( $\mathbf{\square})$ plants cultured at different temperatures.

$\mathrm{H}: 32 / 20^{\circ} \mathrm{C}$ (maximum and minimum temperature), $\mathrm{M}: 30 / 15^{\circ} \mathrm{C}, \mathrm{L}: 28 / 8^{\circ} \mathrm{C}$. Vertical bars indicate $\mathrm{SE}(n=4)$.
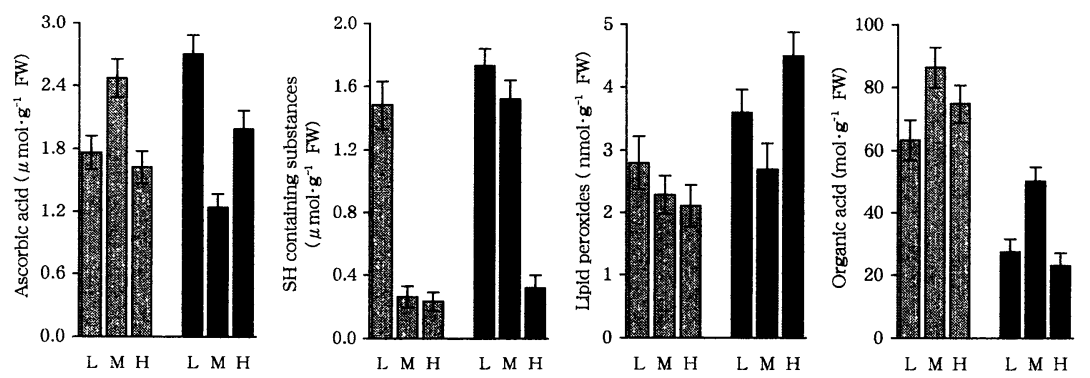

Fig. 3 Concentrations of ascorbic acid, SH containing substances, lipid peroxides and organic acid in leaves of Cattleya (用) and Cymbidium ( $\mathbf{\square}$ ) plants cultured at different temperatures.

Lipid peroxides and organic acid are shown as malondialdehyde and citric acid, respectively. $\mathrm{H}$ : $32 / 20^{\circ} \mathrm{C}$ (maximum and minimum temperature), $\mathrm{M}: 30 / 15^{\circ} \mathrm{C}, \mathrm{L}: 28 / 8^{\circ} \mathrm{C}$. Vertical bars indicate $\mathrm{SE}(n=4)$. 
either high and low cultural temperature than at $30 / 15^{\circ} \mathrm{C}$ (Fig. 3).

\section{DISCUSSION}

The ideal night temperature range for cattleyas is $12.7-15.6^{\circ} \mathrm{C}$ and the day temperature should ideally be about 5.6 degrees higher than it is at night, but favorable conditions remain up to $29.4^{\circ} \mathrm{C}$. On the other hand, for cymbidiums the ideal night and daytime temperatures in winter are $10^{\circ} \mathrm{C}$ and $15.6-18.4^{\circ} \mathrm{C}$, respectively. In summer temperatures above $29.4^{\circ} \mathrm{C}$ are not advantageous (Northen, 1970). Thus, the room temperature of $30 / 15^{\circ} \mathrm{C}$ imposed seems to be a moderate temperature range. Also, $32 / 20^{\circ} \mathrm{C}$ and $28 / 8^{\circ} \mathrm{C}$ are known to be respectively high and low cultural temperatures. No apparent disorders occurred at both high and low temperatures (data not shown). This finding is in agreement with indications that both orchids can tolerate $35^{\circ} \mathrm{C}$ for several hours (Northen, 1970) and with no disorders in cut flowers of Cattleya stored at $4.4^{\circ} \mathrm{C}$ and of Cymbidium stored at $-0.56^{\circ} \mathrm{C}$ (Mastalerz, 1977). However, the high and low temperatures induced changes in scavenging enzyme activities and antioxidant and peroxide levels. They also affected maturation of new shoots and flowering (Li et al., unpublished data).

Defensive reactions of plants to ROS induced by various stresses vary with plant species (Foster and Hess, 1982 ; Feierabend et al., 1992) and factors of causal stresses (Alscher et al., 1997) as well. Cattleya showed lower SOD, APX and CAT activities and higher PPO and AOX activities than Cymbidium. This finding might be due to photosynthetic behaviors of both orchids. CAM plants have photorespiration as $\mathrm{C}_{3}$ plants do (Osmond, 1978 ; Avadhani et al., 1982), but they mitigate it by increasing $\mathrm{CO}_{2}$ levels in their cells by means of releasing $\mathrm{CO}_{2}$ from $\mathrm{C}_{4}$ acids (Osmond, 1978) and by closing their stomata in the daytime. Thus, $\mathrm{H}_{2} \mathrm{O}_{2}$ level in Cattleya leaves is formed by not only the oxidation of glycolate to glyoxylate (Osmond, 1978) but also the reduction of $\mathrm{O}_{2}^{-}$by SOD and is predicted to be low. Hence high SOD, APX and CAT activities might not be necessary for ROS-scavenging systems.

Cultural temperatures different from the moderate temperature induced changes in the activities of the scavenging enzymes. The high temperature for Cattleya enhanced SOD, APX and CAT activities. This fact indicates that formation of ROS continues under the high temperature condition since high temperatures enhance photorespiration (Powles, 1984), induce SOD in the presence of $\mathrm{O}_{2}$ in bacteria and mammals (Fridovich, 1974) and increase CAT in maize scutellum in $\mathrm{H}_{2} \mathrm{O}_{2}$ containing media (Scandalios, 1994). PPO, possibly mediating photoreduction of molecular $\mathrm{O}_{2}$ by PSI in cloroplasts (Vaughn et al., 1988), and AOX also increased activity. Increased PPO activity may serve to cause leaf burning if leaf temperature increases beyond the critical temperature. These results seem to verify the ability of cattleyas to tolerate heat stress. The high cultural temperature for cymbidiums also enhanced activities in scavenging enzymes except for CAT which is reported to reduce at high temperatures and to be associated with induction of photoinhibition at PSII (Feierabent et al., 1992). However, increased lipid peroxides and decreased SHS suggest that the Cymbidium was still struggling against the hot climate to stabilize cell membranes. Besides, a decrease in CAT activity in Cymbidium suggests that APX functioned mainly to detoxify $\mathrm{H}_{2} \mathrm{O}_{2}$ by using increased ascorbic acid.

The low cultural temperature did not affect (or affected slightly) scavenging enzymes in both Cattleya and Cymbidium: APX increased in Cattleya, while CAT decreased in Cymbidium. Two possible explanations may be given : firstly the temperature subjected was not so much low. However, at this temperature PPO and AOX activities and antioxidant levels were influenced. Therefore, it is rational to predict that orchids activate or inactivate the scavenging enzymes during the early cultivation period and then reverted to their original 
activities during further cultivation. The fact that CAT in Cattleya did not respond to the low temperature was contradictory to earlier reports that CAT activity in several crops decreases under this condition (Omran, 1980; Feierabend et al., 1992).

A marked increase in SHS in leaves of Cattleya cultured at the low temperature might not be responsible for ROS-scavenging activities but for the stabilization of proteins to enable this orchid to tolerate cold climate. Zhao and Blumwald (1998) reported that formation of -SSbonds of proteins in Jack pine roots was dependent on reduced gluthatione/oxidized gluthatione mole ratios and concentrations of reduced gluthatione which increased during coldacclimation. Thus, lipid peroxides did not increase, though ascorbic acid decreased at the low cultural temperature. Increases in lipid peroxides in leaves of Cymbidium cultured at both low and high temperatures were inconsistent with increased ascorbic acid levels because ascorbic acid inhibits peroxidation of thylakoid membrane by $\alpha$-tocopherol-mediated reduction (Alscher et al., 1997).

In conclusion, the scavenging enzyme activities as well as the antioxidant and superoxide levels in leaves of Cattleya were different from those of Cymbidium plants. They were influenced by cultural temperatures. Thus, it is clear that the high and low temperatures imposed acted as thermal stress to evoke ROS-scavenging systems. However, some inconsistent results, for example, no (or slight) changes in SOD, APX and CAT activities were found in leaves under the low cultural temperature. To clarify those changes in relation to thermal stress, further elaborate experiments on effects of short-term thermal acclimation are needed.

\section{REFERENCES}

Alscher, R. G., Donahue, J. L., Cramer, C. L. 1997. Reactive oxygen species and antioxidants : relationships in green cells. Phyiol. Plant. 100 : 224-233.

Asada, K. 1992. Ascorbate peroxidase-A hydrogen peroxide-scavenging enzymes in plants. Physiol. Plant. 85 : 235-241.

Avadhani, P. N., Goh, C. J., Rao, A. N., Arditii, J. 1982. Carbon fixation in orchids. In "Orchid Biology, Reviews and Perspectives II” (ed. by Arditti, J.). Cornell Univ. Press, Ithaca, p 173-193.

Beauchamp, C., Fridovich, I. 1971. Superoxide dismutase : Improved assays and an assay applicable to acrylamide gels. Anal. Biochem. 44 : 276-287.

Ellman, G. L. 1959. Tissue sulfhydryl groups. Arch. Biochem. Biophys. 82 : 70-77.

Feierabend, J., Schaan, C., Hertwig, B. 1992. Photoactivation of catalase occurrs under both high- and low-temperature stress conditions and accompanies photoinhibition of photosynthesis II. Plant Physiol. 100 : 1554-1561.

Foster, J. G., Hess, J. L. 1982. Oxygen effects on maize leaf superoxide dismutase and glutathione reductase. Phytochemistry 21 : 1527-1532.

Fridovich, I. 1974. Superoxide dismutase. Adv. Enzymol. 41 : 35-97.

Fridovich, I. 1986. Biological effects of the superoxide radicals. Arch. Biochem. Biophys. 247: 1-11.

Grace, S. C., Logan, B. A. 1996. Acclimation of foliar antioxidant systems to growth irradiance in three broad-leaved evergreen species. Plant Phyiol. 112: 1631-1640.

Hakam, N., Simon, J. P. 1996. Effect of low temperatures on the activity of oxgen-scavenging enzymes in two populations of the $\mathrm{C}_{4}$ grass Echinochloa crusgalli. Physiol. Plant. 97 : 209-216.

Jahnke, L. S., Hull, M. R., Long, S. P. 1991. Chilling stress and oxygen metabolizing enzymes in Zea mays and Zea diploperennis. Plant Cell Environ. 14: 97-104.

Karasawa, K. 1972. Distribution of orchids. In "The Orchids, Culture and Breeding" (ed. by Jpn. Orchid Soc.). Seibundo-Shinkosha, Tokyo, p 95-100.

Mastalerz, J. W. 1977. The Greenhouse Environment. John Wiley \& Sons, New York, p 143.

Northen, R. T. 1970. Home Orchid Growing. Van Nostrand Rheinhold, New York, p 19-28.

Omran, R. G. 1980. Peroxide levels and the activities of catalase, peroxidase, and indoleacetic acid 
oxidase during and after chilling in cucumber seedlings. Plant Physiol. 65 : 407-408.

Osmond, C. B. 1978. Crassulacean acid metabolism: A curiosity in context. Annu. Rev. Plant Phyiol. 29 : $379-414$.

Powles, S. B. 1984. Photooxidation and photoinhibition in higher plants. Annu. Rev. Plant Physiol. 35 : 15-43.

Roe, J. H., Mary, B. M., Oesterling, M. J., Charlotle, M. D. 1948. The determination of diketo-L-gluconic acid, dehydro-L-ascorbic acid, and L-ascorbic acid in the same tissues by 2,4-dinitrophenyl hydrazine method. J. Biol. Chem. 174: 201-208.

Salin, M. L. 1988. Toxic oxygen species and protective systems of the chloroplast. Physiol. Plant. 72 : 681-689.

Scandalios, J. G. 1993. Oxygen stress and superoxide dismutase. Plant Physiol. 101: 7-12.

Scandalios, J. G. 1994. Regulation and properties of plant catalase. In "Causes of Photooxidative Stress and Amelioration of Defense Systems in Plants” (ed. by Foyer, C. H., Mullineaux, P.M.). CRC Press, Boca Raton, p 276-315.

Shen, W., Nada, K., Tachibana, S. 1999. Effect of cold treatment on enzymatic and non enzymatic antioxidant activities in leaves of chilling-tolerant and chilling-sensitive cucumber (Cucumis sativus L.) cultivars. J. Jpn. Soc. Hortic. Sci. 68 : 967-973.

Tien, M., Aust, S. D. 1982. Rabbit liver microsomal lipid peroxidation. Biochim Biophys. Acta 712 : $1-9$.

Vaughn, K. C., Lax, A. R., Duke, S. O. 1988. Polyphenol oxidase: The chloroplast oxidase with no established function. Physiol. Plant. 72: 659-665.

Zhao, S., Blumwald, E. 1998. Changes in oxidant-reduction state and antioxidant enzymes in the roots of Jack pine seedlings during cold acclimation. Physiol. Plant. 104 : 134-142.

\section{〈和文抄録〉}

\section{栽培温度が Cattleya と Cymbidium 葉の抗酸化レベルに及ぼす影響}

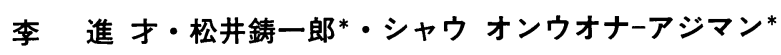

\section{岐阜大学連合農学研究科, * 岐阜大学農学部}

ラン科植物の Brassolaeliocattleya Chian-Tzy Emperor (Cattleya) と Cymbidium Sazanami を最 高/最低温度がそれぞれ $32 / 20^{\circ} \mathrm{C}, 30 / 15^{\circ} \mathrm{C}, 28 / 8^{\circ} \mathrm{C}$ の条件で 2 力月栽培した. Cattleya の葉のス一 パーオキシドジスムターゼ (SOD), アスコルビン酸ペルオキシダーゼ (APX) と, カタラーゼ (CAT) 活性は Cymbidium に比べ低く，ポリフェノールオキシダーゼ (PPO) とアスコルビン酸 オキシダーゼ (AOX) 活性は高かった. 高温栽培ではCattleya はこれらの酸素のすべて, Cymbidium は CAT を除く四つの酵素活性を高めた。低温栽培は Cattleya では APX 活性のみが 上昇し, Cymbidium では CAT 活性のみが低下し, 高温栽培に比べて影響が少なかった.二つのラ ンともPPO 活性が上昇し, AOX 活性は低下した。抗酸化物質のレベルについて Cattleyaでは高, 低温栽培条件でアスコルビン酸含量は低下したが, Cymbidium では増加した. 前者は低温栽培で は SH 基含量が著しく増加し, 後者は高温栽培で著しく低下した. 葉中の過酸化脂質含量は高, 低 いずれの栽培温度でもCattleya では変化が少なかったが, Cymbidium で増大した. 